\title{
Sea mammals in archaeological sites on the southern coast of Brazil
}

\author{
Pedro Volkmer de Castilho* \\ Paulo César Simões-Lopes**
}

CASTILHO, P.V.; SIMÕES-LOPES, P.C. Sea mammals in archaeological sites on the southern coast of Brazil. Revista do Museu de Arqueologia e Etnologia, São Paulo, 18: 101-113, 2008.

Resumo: Foram avaliados restos faunísticos de 11 sítios arqueológicos do litoral centro-norte de Santa Catarina, sul do Brasil, com datações variando entre 5000 e 1000 A.P. Apesar de os sítios arqueológicos apresentarem ocupações humanas de cultura material diferenciada, a diversidade de espécies de mamíferos marinhos foi semelhante entre eles. Foram diagnosticadas três espécies de pinípedes e nove de cetáceos. As estruturas que mais contribuíram para a identificação das espécies foram o complexo periótico-timpânico, os dentes, os crânios e os ossos dos membros. A quantificação das peças de mamíferos marinhos sugere uma abordagem mais cautelosa na caracterização das atividades humanas pré-coloniais, pois estes grupos culturais podem ter utilizado lobos-marinhos, baleias e golfinhos com maior freqüência do que imaginado, além de indicarem a presença de habilidades náuticas.

Palavras-chave: Mamíferos marinhos - Zooarqueologia - Ossos.

\section{Introduction}

$\mathrm{t}$ is estimated that the first records of

human occupation on the coast of Santa Catarina State, Brazil, happened between 6,000 and 5,000 years before present (BP). According to the archaeological surveys of Bigarella (1949), Duarte (1971), Eble (1971) and Rohr $(1977 \mathrm{a}, \mathrm{b})$ on the coast of Santa

$\left.{ }^{*}\right)$ Universidade do Estado de Santa Catarina UDESC/LAGES.

volkmerdecastilho@yahoo.com.br.

$\left.{ }^{* *}\right)$ Laboratório de Mamíferos Aquáticos, Departamento de Ecologia e Zoologia (ECZ).

Universidade Federal de Santa Catarina. lamaqs1@ccb.ufsc.br
Catarina State, archaeological sites were found to be distributed along the coast in places of high productivity such as mangroves, rivers and lakes.

The hunter-gatherer-fishers were the first known human groups, which are characterized by fishing, hunting and gathering animal and vegetal resources. These groups occupied the coast for at least 4,000 years, leaving their vestiges in archaeological sites that were identified by the artificial seashell accumulations traditionally known as sambaquis, and by the fish, bird, reptile, mammal and vegetal remains they contained (Bandeira 1992; Figuti 1999; Gaspar 1999; De Masi 2001). More recently, there was a human re-occupation in the coast by the ceramists, people skilled in the use and fabrication of ceramics. This cultural group 
subsisted preferentially on sea resources, principally fish (Fossari 2004).

The archaeological sites of ceramic societies from the coast produce carbon 14 (14C) dates around 1,500 and 1,000 years B.P, and their largest populations occupied several other niches, including occupation on the sambaquis (Schmitz et al. 1993). Neves (1988) reported that the ceramic societies were human groups morphologically different from the hunter-gatherer-fishers, but Neves \& Blum (1998) detected evidences of genetic flow among these ceramic and non-ceramic societies.

Independently from the genetic analysis, the material culture difference indicates the absence of relation among the two groups. The ceramic people presented activities as food storing and cooking strategy, a fact not observed among the hunter-gatherer-fishers (Prous 1992; Lima 2000).

According to Fossari (2004), the ceramic societies were good navigators, supporting the idea that this would be a human group responsible for the engravings at the surrounding islands at the Santa Catarina coast.

The faunal analyses of the archaeological sites from the southern region of Brazil aimed until now to describe the food habits of the hunter-gather-fisher populations. However, the majority of these studies use very broad taxonomic groups (e.g., orders and classes) or deal with food items through common names (e.g., dolphins and whales) (Rohr 1977a,b; Prous 1992; Schmitz et al. 1992; 1993; 1999; Gaspar 1999).

The interpretation of food resources contributes to the human comprehension of the Brazilian coastal sector during the last 12,000 years. Several authors have argued that the utilization of the coastal sector in several part of the globe was an important survival strategy (Colten \& Arnold 1998; Glassow 1999; Porcasi et al. 1999), especially in terms of subsistence, allowing new areas for the dispersion or exploration of new resources for human populations. Tens of cases are registered in the Northern Hemisphere, where distinct cultural groups fixed along the coast intending to obtain resources in large quantities (Porcasi \& Fujita 2000).

Sea mammals comprise one of the most used food resources of several pre-historic human groups world-wide. Among them, there are examples of specialized exploitation of dolphins (Delphinus delphis) on the Japanese coast during the Jomon period 5,000 year B.P. (Hiraguchi 2003); the selective hunting of seals, sea lions and fur seals at the Californian coast (Lyman 1989; Porcasi \& Fujita 2000); the hunting strategies during the migration of the bowhead whale (Balaena mysticetus), white whale (Delphinapterus leucas) and narwhal (Monodon monocerus) in the northern region of Canada (Savelle 1994; 1995; 1997; Savelle \& McCartney 1999); and the vestige of hunting pressure upon the North Atlantic right whale (Eubalaena glacialis $[=E$. australis]) at the South African coast (Jerardino \& Parkington 1993) and Namibian coast (Smith \& Kinahan 1984). Moreover, at the shores of Beagle's channel, in Ushuaia, Schiavini (1987) produced archaeological evidence that demonstrate the intensive use of two pinniped species, Arctocephalus australis and Otaria flavescens.

Currently, there are 85 species of cetaceans, 16 of otariids and 19 of phocids (Perrin et al. 2002). Approximately a quarter of these species live on or frequent the Santa Catarina coast, which results in a region of high diversity of species (Simões-Lopes \& Ximenez 1993; SimõesLopes et al. 1995; Cherem et al. 2004).

This work has as its objectives the followings: I - analyze the archaeological collections of eleven sites dug on the centre-northern coast of the Santa Catarina State, southern Brazil, whose dates are within the last 5,000 years; II - identify the sea mammal species that were found in the faunal remains of hunter-gatherer-fishers and ceramic societies; III - compare the current and archaeological sea mammal diversities; IV discuss the implications of hunting and collecting of the species found at the analyzed sites.

\section{Materials and Methods}

Faunal remains were analyzed from eleven archaeological sites of hunter-gatherer- fisher and ceramic populations located at the centre-northern portion of the Santa Catarina coast dating between 900 and 5,000 years B.P (Fig. 1, Table 1). These sites were mapped during the archaeological surveys of Bigarella (1949), Duarte (1971), Eble (1971), Rohr (1977a,b) and Oliveira (1996). 


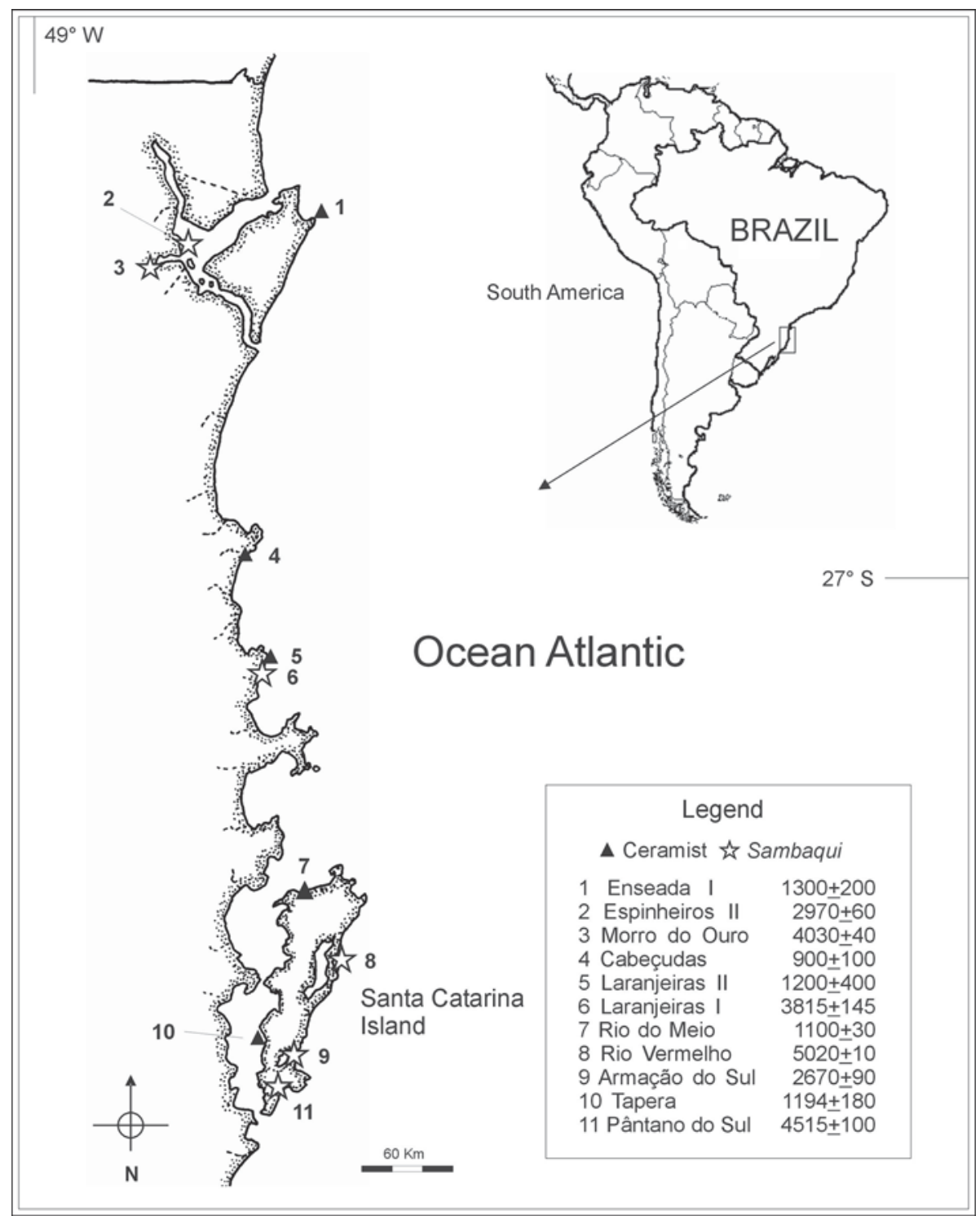

Fig. 1. Spatial distribution and cultural classification of the archaeological sites at the centrenorthern part of the Santa Catarina Coast, Southern Brazil, analyzed in this study.

The skeletal remains of sea mammals were selected, numbered and compared to specimens of the current fauna deposited in the mammal collection of the Departamento de Ecologia e Zoologia da Universidade Federal de Santa Catarina (Florianopolis/Brazil), from the Museu Oceanográfico do Vale do Itajaii (Itajai/Brazil), from the Grupo de Estudos de Mamíferos Aquáticos do Rio Grande do Sul (Porto Alegre/Brazil), from
División de Zoología de Vertebrados del Museo de La Plata (La Plata/Argentina), and from the División de Mastozoología del Museo Argentino de Ciencias Naturales (Buenos Aires/ Argentina).

The acronyms of archaeological sites and museums are the followings: $\mathrm{MU} / \mathrm{UFSC}=$ Museu Universitário Oswaldo Cabral/ Universidade Federal de Santa Catarina - Florianópolis; MASJ = Museu Arqueológico do Sambaqui de 
Table 1

\begin{tabular}{lllll}
\multicolumn{4}{l}{ Rabiocarbon dates, periods, references and collections for archaeological sites on the coast of Santa Catarina } \\
\hline Archaeological Sites & Date & Periods & Museums & \multicolumn{1}{c}{ Source } \\
\hline \hline Cabeçudas & $900+100$ & Ceramic & MHS & Schmitz \& Verardi 1996 \\
Rio do Meio & $1170 \pm 60$ & Ceramic & MU/UFSC & Fossari 2004 \\
Tapera & $1194 \pm 180$ & Ceramic & MHS & Schmitz et al. 1993 \\
Laranjeiras II & $1200+400$ & Ceramic & MHS & Schmitz et al. 1993 \\
Enseada I & $1390+40$ & Ceramic & MU/UFSC & Bandeira 2004 \\
Armação do Sul & $2670 \pm 90$ & Preceramic & MHS & Schmitz et al. 1992 \\
Espinheiros II & $2970 \pm 60$ & Preceramic & MASJ & Afonso \& Blasis 1994 \\
Laranjeiras I & $3815 \pm 145$ & Preceramic & MHS & Schmitz \& Bitencourt 1996 \\
Morro do Ouro & $4030 \pm 40$ & Preceramic & MASJ & Oliveira 1996 \\
Pântano do Sul & $4515 \pm 100$ & Preceramic & MHS & Schmitz \& Bitencourt 1996 \\
Porto do Rio Vermelho & $5020 \pm 10$ & Preceramic & UNISUL & De Masi 2001 \\
\hline
\end{tabular}

Joinville - Joinville; MHS = Museu Homem do Sambaqui - Florianópolis; UNISUL = Laboratório de Arqueologia da Universidade do Sul de Santa Catarina - Palhoça.

Two quantifications in measures were used to describe the abundance of faunal remains: NISP (number of identified specimens), which corresponds to the number of identified pieces, and MNI (minimum number of individuals). $\mathrm{MNI}$ is here defined as the minimum number of possible individuals for each species, considering the repetition of the skeleton structures, despites the correction of possible distortions of NISP due to the bone preservation and fragmentation (Chaplin 1971; Klein \& Cruz-Uribe 1984; Marshall \& Pilgram 1993; Reitz \& Wing 1999).

For the assessment of quantitative variables of the frequency indexes (NISP and MNI), there were employed the Pearson correlation coefficients (Zar 1999).

\section{Results}

For the eleven studied sites, 2,612 elements of sea mammals were identified (Fig. 2). The quantifications of the skeletal remains showed that mysticets were not found at the Tapera site, located at the inner waters of Sul Bay on Santa Catarina Island, but they were found in Espinheiros II as in Morro do Ouro, located in evenness and inner waters of the Babitonga Bay, was also the one that reached the highest percentage of mysticete elements (97.7\%) followed by the Porto do Rio Vermelho (93\%) and Cabeçudas (82\%) sites.

Odontocetes were recorded in all the collections in proportions varying from $2 \%$ to $93 \%$ of NISP (Fig. 2). The largest percentages of odontocetes were reported at the sites of Rio do Meio (93\%), Armação (73\%), and Morro do Ouro (70\%); however the sites with highest number of identified odontocete bones were the Enseada I (NISP = 278) and Pântano do Sul $(\mathrm{NISP}=694)$ ones, respectively.

When assessing the faunal remains in relation to the human occupations, we verified that the hunter-gatherer-fisher (preceramic) sites presented the largest proportion of odontocete and mysticete bones, when compared the pinnipeds remains. Excepting in the Tapera site, where there were $73 \%$ pinnipeds and $27 \%$ odontocetes, without the presence of mysticetes (Fig. 2).

There were 131 bones identified as pinnipeds, 46 of them being identified to the genus Arctocephalus. Three pinniped species were confirmed on the basis of 25 pieces consisting of teeth, skulls and bones belonging to South American fur seal, Arctocephalus australis, with the remaining pieces belonging to Subantarctic fur seal, Arctocephalus tropicalis, and to South America sea lion, Otaria flavescens (Table 2).

Among the cetaceans, the Mysticeti are represented by a large number of identified pieces $($ NISP $=1087$; Table 3$)$, a result of the numerous pieces of vertebrae, epiphyses, and 


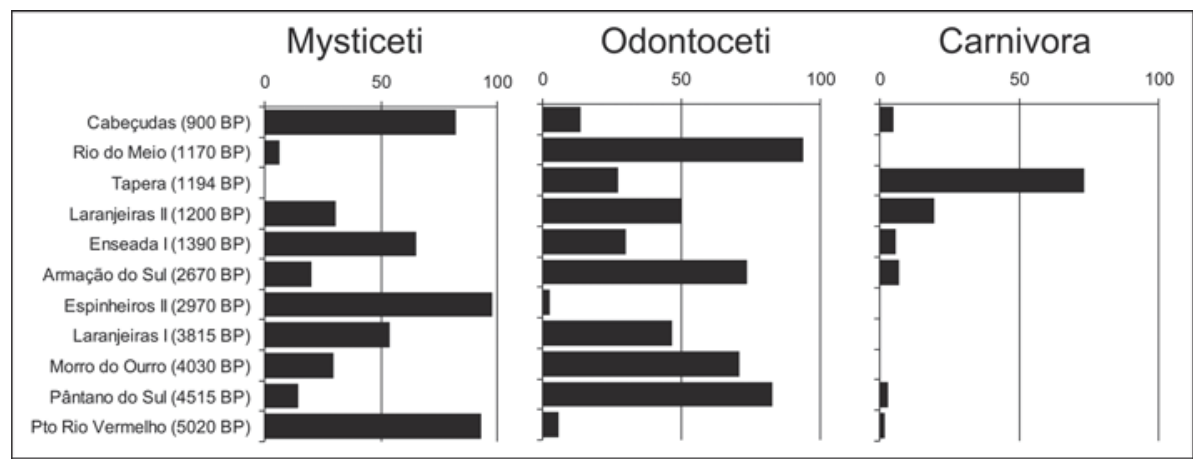

Fig. 2. Data regarding the faunal skeletal remain distribution in large taxonomical groups at the eleven archaeological sites.

Table 2

\begin{tabular}{lrlllllllr}
\hline \multicolumn{7}{c}{ Pinnipeds found at Santa Catarina Coast sites } \\
\hline \multicolumn{7}{c}{ Preceramic Periods } & \multicolumn{7}{c}{ Ceramic Periods } \\
\hline Taxonomic Classification & NISP & $\%$ & MINI & $\%$ & NISP & $\%$ & MINI & $\%$ & NISP \\
\hline \hline Ordem Carnivora & & & & & & & & & \\
Family Otariidae & 3 & 10 & & & 48 & 47,52 & & \\
Otaria flavescens (Shaw 1800) & 0 & 0 & 0 & 6 & 5,94 & 1 & 5 \\
Arctocephalus sp. & 16 & 53,33 & 4 & 30 & 29,70 & 2 & 46 \\
Arctocephalus australis (Zimmermann 1783) & 8 & 26,67 & 4 & 17 & 16,83 & 3 & 25 \\
Arctocephalus tropicalis (Gray 1872) & 3 & 10 & 3 & 0 & 0 & 0 & 3 \\
\hline & 30 & & 11 & 101 & 6 & 131 \\
\hline
\end{tabular}

ribs. The rorquals (family Balaenopteridae) were identified only to the family level. A distinctive feature of the skeleton of southern right whale, Eubalaena australis (family Balaenidae) is due to presence from the periotic-tympanic complex, whose characteristics - ventral-medial flat face of the tympanic and the cochlear portion - allowed the identification of the species.

At least eight species of small cetaceans were confirmed (Table 3). The outstanding species was the bottlenose dolphin, Tursiops truncatus, with 154 skeletal remains, among them 82 teeth, as well as other bones identified as humerus and radius. In the second place, there is the Franciscana (La Plata dolphin), Pontoporia blainvillei, with 54 bones, represented by the cranium vertex, mandibles, and lumbar vertebrae.

The Delphinidae family is represented by 978 pieces, principally vertebrae of small dolphins, with doubtful identifications.
A minimum number of 17 pinnipeds and of 80 cetaceans was calculated (Table 2 and 3). The correlation between NISP and MNI points to a positive and significant correspondence among the indexes, even with the low Pearson coefficient correlation $(r 2=0.478 ; p=0.002)$. The ease with which archaeological mysticete bone fragments, and the consequently large quantity of mysticete fragments in the eleven assemblages, may contribute to the low correlation coefficient.

The pinniped species found at the archaeological sites were identified principally through the dental morphology as well as through the comparative exemplars of killer whale and the rough-toothed dolphin (Fig. 3).

The cetaceans were identified using the cranial characters, but the axis was a structure of huge diagnostic value for Pontoporia blainvillei, the unique species present at the Brazilian coast, where does not occur the fusion of atlas with axis through life. 
Table 3

\begin{tabular}{|c|c|c|c|c|c|c|c|c|c|}
\hline \multicolumn{10}{|c|}{ Cetaceans found at Santa Catarina Coast sites } \\
\hline & \multicolumn{4}{|c|}{ Preceramic Periods } & \multicolumn{4}{|c|}{ Ceramic Periods } & \multirow[b]{2}{*}{ NISP } \\
\hline Taxonomic Classification & NISP & $\%$ & MINI & $\%$ & NISP & $\%$ & MINI & $\%$ & \\
\hline \multicolumn{10}{|l|}{ Ordem Cetacea } \\
\hline Subordem Mysticeti & 380 & 30,13 & 5 & & 707 & 57,62 & 4 & & 1087 \\
\hline \multicolumn{10}{|l|}{ Family Balaenidae } \\
\hline Eubalaena australis (Desmoulins, 1822) & 30 & 2,38 & 11 & & 11 & 0,90 & 4 & & 41 \\
\hline $\begin{array}{l}\text { Family Balaenopteridae } \\
\text { Subordem Odontoceti }\end{array}$ & 13 & 1,03 & 4 & & 22 & 1,79 & 2 & & 35 \\
\hline Family Delphinidae & 648 & 51,39 & 6 & & 330 & 26,89 & 5 & & 978 \\
\hline Sotalia guianensis (P.J. van Bénéden, 1864) & 2 & 0,16 & 1 & & 1 & 0,08 & 1 & & 3 \\
\hline Stenella frontalis (G. Cuvier, 1829) & 41 & 3,25 & 4 & & 10 & 0,81 & 1 & & 51 \\
\hline Stenella sp. & 9 & 0,71 & 4 & & 20 & 1,63 & 0 & & 29 \\
\hline Delphinus capensis (Gray, 1828) & 15 & 1,19 & 3 & & 22 & 1,79 & 2 & & 37 \\
\hline Steno bredanensis (Lesson, 1828) & 1 & 0,08 & 1 & & 5 & 0,41 & 2 & & 6 \\
\hline Tursiops truncatus (Montagu, 1821) & 91 & 7,22 & 5 & & 63 & 5,13 & 7 & & 154 \\
\hline Pseudorca crassidens (Owen, 1846) & 4 & 0,32 & 1 & & 1 & 0,08 & 1 & & 5 \\
\hline Orcinus orca (Linnaeus, 1758) & 1 & 0,08 & 1 & & 0 & 0 & 0 & & 1 \\
\hline \multicolumn{10}{|l|}{ Family Pontoporiidae } \\
\hline $\begin{array}{l}\text { Pontoporia blainvillei (Gervais \& } \\
\text { d'Orbigny, 1844) }\end{array}$ & 20 & 1,59 & 5 & & 34 & 2,77 & 9 & & 54 \\
\hline \multirow[t]{2}{*}{ Unidentified Cetaceans } & 6 & 0,48 & & & 1 & 0,08 & & & 7 \\
\hline & 1261 & & 46 & & 1227 & & 34 & & \\
\hline
\end{tabular}

Among the cranial bones that most contributed to specific identification are the maxillary, pre-maxillary, tympanic, lachrymal, and dentary bones (Fig. 4). Teeth were valuable diagnostic elements due to their importance in the pinnipeds and small cetaceans. The bones of the forelimb, esp. the radius, and hind limb, esp. the femur (in pinnipeds), also were of considerable importance. Despite their substantial abundance, the vertebrae constitute an anatomical sector of complex identification, which was accentuated by the imperfect bone preservation.

\section{Discussion}

\section{Current fauna versus archaeofauna}

Currently, 25 species of cetaceans and six of pinnipeds are confirmed for the Santa Catarina coast (Simões-Lopes \& Ximenez 1993; SimõesLopes et al. 1995; Cherem et al. 2004). These data have been accumulating since the 1980s, and they are based on field observations and strandings.

Between the years of 1983 and 2004, around 220 carcasses of sea mammals were collected by the Laboratório de Mamiferos Aquáticos da Universidade Federal de Santa Catarina, with a concentration among the months of July and November (Castilho et al. 2004). The coastal species like Sotalia guianensis, Pontoporia blainvillei and Tursiops truncatus were the most frequent ones. The pinnipeds correspond to $18 \%$ of the samplings, not being registered in the years of 1983, 1991, 1995, 1997 and 2001. The southern fur seal, Arctocephalus australis, was the most frequent species (Simões-Lopes et al. 1995; Castilho et al. 2004).

The earliest sea mammal occurrence at a Brazilian archaeological site was found at Camboinhas in Rio de Janeiro, dating 7,958 + 224 B.P. where Cunha et al. (1986) registered six 
Pedro Volkmer de Castilho
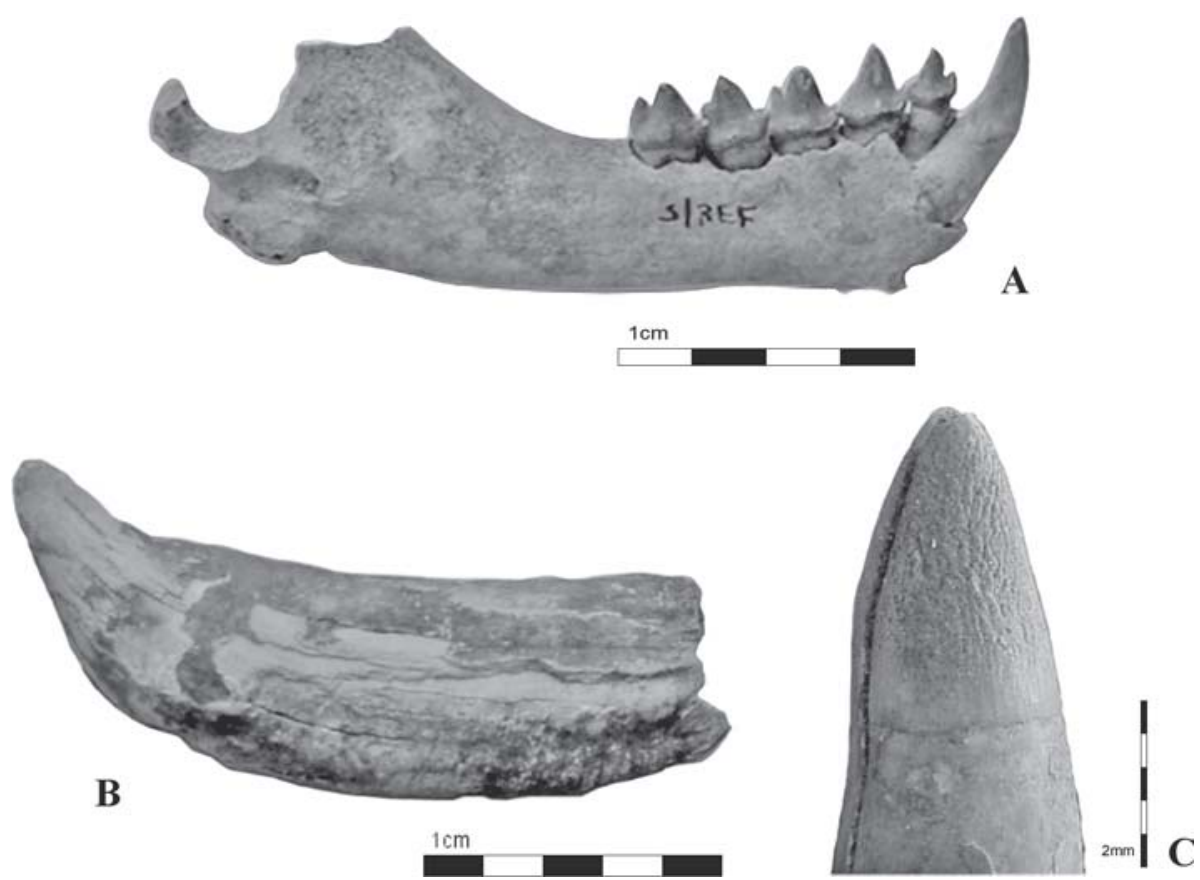

Fig. 3. Species identified principally through the dental morphology. A. Arctocephalus australis; B. Orcinus orca and C. Steno bredanensis.
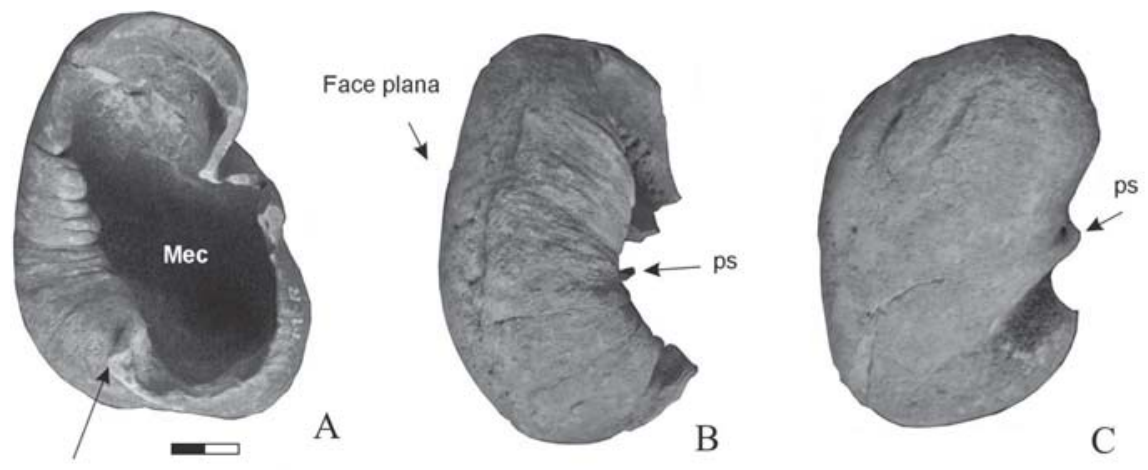

pp
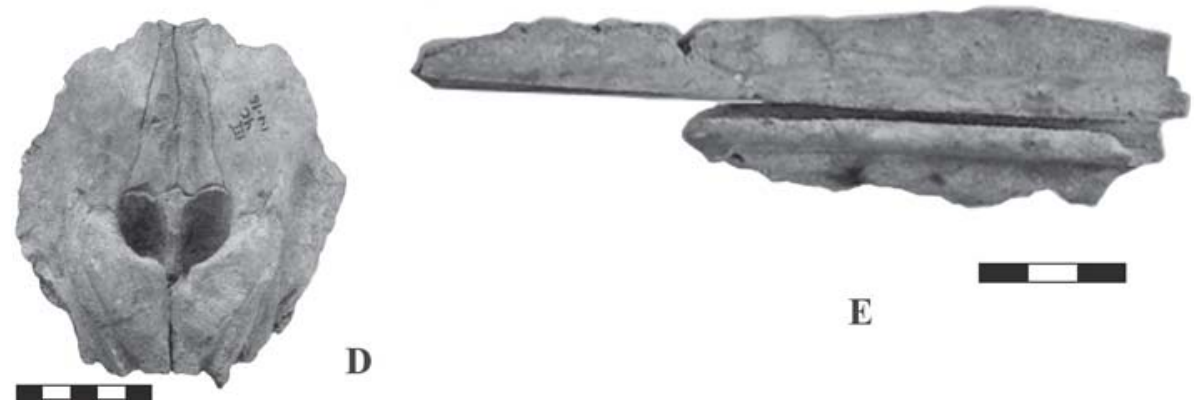

$\mathbf{E}$

Fig. 4. Diversity of identified marine mammals in archaeological sites on the coast of Santa Catarina. A., B. and C. views of the periotic-tympanic of Eubalaena australis; D. Pontoporia blainvillei, and E. Delphinus capensis. 
vertebrae of Sotalia sp. (=S. guianensis), two tympanic bones belonging to Megaptera novaeangliae and to Eubalaena glacialis (=E. australis). Apart from these entries, the presence of sea mammal bones is mentioned in sites at Rio de Janeiro, São Paulo, Paraná and Santa Catarina coasts (Prous 1992).

Until now, the archaeological research from Santa Catarina State has approached the animal species that have occurred at the archaeological sites in a limited (or perfunctory) and merely descriptive manner. The articles of Rohr (1977a) and Schmitz \& Bitencourt (1996) mention teeth and bones identified as Tursiops truncatus and Delphinus delphis, bones of Otaria flavescens and Arctocephalus australis in the skeletal remains of Pântano do Sul. The same happens with Schmitz et al. (1993) where the presence of common dolphins and bottlenose dolphins is cited in the Laranjeiras II sites. For the archaeological site of Tapera, the presence of balenids, otariids and bottlenose dolphins (Silva et al. 1990) was noted, and at Cabeçudas, the Pontoporia genus was mentioned for the first time (Schmitz \& Verardi 1996). Recently, Castilho \& Simões-Lopes (2001) identified nine species of sea mammals at the sites of Rio do Meio and Porto do Rio Vermelho, highlighting the need for re-assessment of the skeletal remains of the Santa Catarina coast.

According to the results obtained in the present study, there was a significant increase $(58 \%)$ in the number of known species from the Holocene fauna of the Santa Catarina coast. Until this work, only five species had been identified, and now there are recorded 12 sea mammal species. The cetaceans Tursiops truncatus, Pontoporia blainvillei, and Eubalaena australis and the fur seal Arctocephalus australis were the most frequent species in the skeletal remains, and they represent $39 \%$ of sea mammals taxa currently known.

This diversity of species found at the Santa Catarina archaeological sites is due, in part, to the geographical location. This is a zone of contact of the two biggest sea-streams of the Occidental South Atlantic, the Malvinas (Falkland) stream and the Brazil streams (Simões-Lopes \& Ximenez, 1993). The high diversity is also the result of greater attention to the identification of the archaeological bones. In the skeletal remains of Northern Hemisphere archaeological sites, such high diversity of species is not common (Friesen \& Arnold 1995; Hiraguchi 2003) or they appear to increase the diversity by including large cetacean (Porcasi \& Fujita 2000; Mulville 2002).

The preservation success of the fragmented bones is due, mainly, to the environment where they were deposited. The accumulation of seashells and beach sands confer an environment rich in calcium carbonate, compacted enough to keep the porous bones of the cetaceans in favorable preservation conditions.

\section{Human populations}

These hunter-gatherer-fishers (preceramic) and ceramic period populations have a distinct material culture, and they have built sites of differentiated form and structure, based on their environmental knowledge of food and fresh water resources (Prous 1992). However, the differences between these peoples disappear regarding sea mammals. The skeletal remains indicate that the sea mammals were used similarly by both pre-colonial populations. Through the identified bones and fragments, similarities are noted in the sampled species, in the bone processing, and in preservation.

Among all the assessed archaeological sites, only Rio do Meio (ceramist), located at the northern region of the Santa Catarina Island, has not revealed any human burial, being characterized as a processing site (Fossari 2004). Hiraguchi (2003) reports a similar case, where several sites on the coast of Hokkaido, Japan, do not contain burials. On the other hand, there were abundant crania, scapulae and humeri of small cetaceans.

The social and/or religious importance of the cetaceans for the pre-colonial populations is not well known; nevertheless, the found zoolithics (zoomorphic petroglyphs) show the presence of dolphins (Rohr 1977a) and whales (Rohr 1967) among the represented animals. Schmitz et al. (1993) mentioned the presence of a whale mandible associated to the 107th burial at Laranjeiras II, suggesting that it would provide 
protection against the ocean water due to its disposition parallel to the beach. This explanation seems improbable because the site has not suffered encroachment from the ocean. This case, as well as the case registered by Tenório (1999) for the Ilhote de Leste archaeological site (RJ), where a whole dolphin was found on top of the burial appear to be isolated ritual examples. The use of cetaceans in burial rituals is neither well defined nor known at present.

\section{The implications of hunting versus strandings}

Several whale species use the Santa Catarina coast, particularly the southern right whale, rorquals and sperm whale. The southern right whale, Eubalaena australis, is slow and swims close to the coast looking for protection for themselves and their calves in coves and bays (Payne 2000). The capture of southern right whale could be a viable practice, taking into account the hunting artifact (harpoons) found at the coastal archaeological sites (Prous 1992). Furthermore, the Pântano do Sul is, nowadays, one of the zones of concentration and parturition of right whale (Simões-Lopes et al. 1992). Regarding the rorquals (Balaenoptera), they reached higher speed ranging from 5 to even $35 \mathrm{~km} / \mathrm{h}$ (Sears 2002), a fact that makes unviable the pursuit and hunting of these species buy the pre-colonial populations of the Santa Catarina coast.

Gregarious odontocetes, such as the beluga whale and narwhals, were hunted by the Eskimo populations, which influences directly the subsistence and organization of these human groups (Friesen \& Arnold 1995). According to the evidence left at processing sites, the meat and fat were taken in small quantities to places of residence far from the processing places - a situation that points to an organized collecting system (Savelle 1995).

Small cetaceans are not usually hunted through direct pursuit but through net fishing, which classifies the hunting an opportunistic foraging activity in which animals were drawn into the nets or were scavenged when they were found dead on the beaches. The unequivocal evidence of fishing activity during the pre-colonial period is the abundance of fishes in the skeletal remains and net weights. (Rohr 1977a; Prous 1992; De Masi 2001). Further, Rohr (1967) describes the existence of vegetal fibers conserved in mud in the municipality of Alfredo Wagner, Santa Catarina plateau, dating around 3,000 years B.P. that supposedly could be used as nets. De Masi (2001) found compound fishhooks, suggesting that fish were caught rather than hunted with lances and arrows as mentioned in previous studies (e.g., Rohr 1977a; Prous 1992).

The harpoon absence and other hunt marks and processing suggest that the whales as well as the pinnipeds were not intensively exploited resources due to the high operational cost of hunting and transportation (Castilho 2005). In the Canadian high arctic, bowhead whales (Balaena mysticetus) were intercepted during their migration during the warmer months of the year from sites that were deliberately located along their migration routes (Savelle \& McCartney 1999). At these areas, there are concentrations of bones such as scapulae, vertebrae and ribs. The crania and mandible were rarely transported and were used in the construction of winter shelters (Savelle 1997; Savelle et al. 2001). In southern Brazil, the whales must have been butchered on the beach close to the surf and their remains abandoned there. Moreover, boats and harpoons on the bones would be an evidence of hunting; however, such evidence was not recorded at the analyzed archaeological sites. The only evidence of human activities (probable scavenging) is some cut marks and chop marks made by sharp tools such as knives during butchering and disarticulation. Monks (2001) found similarities in the process of butchering and disarticulation the whales hunted by recent Thule Eskimos with the marks found in archaeological bones, but Glassow (2002) still does not have a concrete chance to determine how the dolphins were hunted.

\section{Conclusions}

Observing the results obtained at the studied archaeological sites, we can assert that these precolonial populations from the Santa Catarina coast were not specialized in sea- mammal 
hunting but certainly were reliant on a diet comprised of fish, mollusc, bird, vegetal, terrestrial and sea mammals as attested at these 11 archaeological sites on the Brazilian Coast (Lima 2000; De Masi 2001; Gaspar 2003; Fossari 2004).

The re-assessed and new archaeological data update the interpretation of human activities on the coast, providing evidence of the importance of sea mammals as resource in the dietary regime and the material culture of the hunter-gathererfishers and ceramic populations of the area.

The absence of evidence pointing to the intensive exploitation of sea mammal resources suggests that the identified species were used at low intensity to supply nutritional demands, raw material for artifact production, oil extraction for fuel or to eat with dried foods. Monks (2005) suggests the analysis of these whale bone assemblages in terms of their oil utility indicates that those bones containing relatively large amounts of oil are the most likely to be transported onto the site. Some lines of inquiry must be explored in further studies regarding the dietary contribution of the meat, the population demography of the recovered individuals and the human modifications left on the bones in order to provide a better of the presence of sea mammal species in the culture of pre-colonial populations of Santa Catarina State.

\section{Acknowledgment}

We thank Professor S. Linhares from the MHS for the archaeological material concessions; MU/UFSC for the support given by Archaeologist T.D. Fossari, and the aid from H.J. Graipel Júnior; MASJ for the attention and dedication of A.M. Pereira dos Santos and D. Bandeira, who made possible the archaeological material assessment, offering all the required structure, equipments and bibliographic references. The Pós-Graduação em Zoologia da Universidade Federal do Paraná and CNPq for the financial support during the development of the project.

CASTILHO, P.V.; SIMÕES-LOPES, P.C. Sea mammals in archaeological sites on the southern coast of Brazil. Revista do Museu de Arqueologia e Etnologia, São Paulo, 18: 101-113, 2008.

\begin{abstract}
Animal remains were assessed from eleven archaeological sites dating between 5,000 and 1,000 B.P on the coast of Santa Catarina State, southern Brazil. Although the archaeological sites presented differentiated material culture of human occupation, the mammal species diversity was similar among them. Three species of pinnipeds and nine species of cetaceans were identified. The structures that most contribute to the species identifications were the periotictympanic complex, teeth, the cranium, radio and femur. The quantification of sea mammal elements suggest a more accurate approach for the characterization of pre-colonial human dietary because these cultural groups might have used sea lions, fur seal, whales and dolphins with greater frequency than previously supposed, despite the indications of their nautical capabilities.
\end{abstract}

Keywords: Marine mammals - Zooarchaeology - Bones. 


\section{References}

AFONSO, M.C.; BLASIS, P.A.D.

1994 Formação de um grande sambaqui: Espinheiros II, um estudo de caso. Revista do Museu de Arqueologia e Etnologia, 4: 21-30.

BANDEIRA, D.R.

1992 Mudança na estratégia de subsistência, o sítio arqueológico Enseada I - um estudo de caso. Master Thesis, Florianópolis, Universidade Federal de Santa Catarina, Departamento de Antropologia Social.

2004 Ceramistas pré-coloniais da Baía da Babitonga - Arqueologia e Etnicidade. Doctoral Thesis, Campinas, Universidade Estadual de Campinas.

BIGARELLA, J.J.

1949 Contribuição ao Estudo da Planície Sedimentar da parte Norte da Ilha de Santa Catarina. Arquivos de Biologia e Tecnologia, 4 (16): 107-140.

CASTILHO, P.V.

2005 Mamíferos marinhos: um recurso de populações humanas pré- coloniais do litoral catarinense. Doctoral Thesis, Curitiba, Universidade Federal do Paraná.

CASTILHO, P.V.; SIMÕES-LOPES, P.C.

2001 Zooarqueologia dos mamíferos aquáticos e semi-aquáticos da Ilha de Santa Catarina, sul do Brasil. Revista Brasileira de Zoologia, 18 (3): 719-727.

CASTILHO, P.V.; SILVA, C.L., SIMÕES-LOPES, P.C.

2004 Vinte anos de registros de Mamíferos Marinhos em Santa Catarina: Revisão dos encalhes e sazonalidade. XXV Congresso Brasileiro de Zoologia, Brasília. Anais: 274.

CHAPLIN, R.E.

1971 The study of animal bones from archaeological sites. New York: Seminar Press.

CHEREM, J.J.; SIMÕES-LOPES, P.C; ALTHOFF, S.L.; GRAIPEL, M.E.

2004 Lista dos Mamíferos de Santa Catarina, sul do Brasil. Mastozoologia Neotropical, 11 (2): 151- 184.

COLTEN, R.H., ARNOLD, J.E.

1998 Prehistoric marine mammal hunting on California's Northern Channels Islands. American Antiquity, 63 (4): 679-701.

CUNHA, F.L.S; CARVALHO, A.L., NUNAN, G.W.A.

1986 Ocorrência de vertebrados holocênicos marinhos, Elasmobranchii e Cetacea no
Sambaqui de Camboinhas, Itaipu, Niterói, estado do Rio de Janeiro. Revista de Arqueologia, 3 (1): 52- 56.

DE MASI, M.A.N.

2001 Pescadores Coletores da Costa Sul do Brasil. Pesquisas, Antropologia, 57: 1-136.

DUARTE, G.M.

1971 Distribuição e Localização de Sítios Arqueológicos tipo Sambaqui, na Ilha de Santa Catarina. Anais Museu de Antropologia, UFSC, 4 (1): 31-60.

EBLE, A.B.

1971 Considerações sobre o "Sítio Arqueológico”. Anais Museu de Antropologia, UFSC, 4 (1): 71-77.

FIGUTI, L.

1999 Economia/alimentação na pré-história do litoral de São Paulo. In: Tenório, M.C. (Ed.) Pré-História da Terra Brasilis. Rio de Janeiro, Ed. UFRJ: 197-204.

FOSSARI, T.D.

2004 A população pré-colonial Jê na paisagem da Ilha de Santa Catarina. Doctoral Thesis, Universidade Federal de Santa Catarina.

FRIESEN, T.M.; ARNOLD, C.D.

1995 Zooarchaeology of a focal resource: Dietary importance of beluga whales to the precontact Mackenzie Inuit. Artic, 48 (1): 22-30.

GASPAR, M.D.

1999 Os ocupantes pré-históricos do litoral brasileiro. In: Tenório, M.C. (Ed.) PréHistória da Terra Brasilis, Rio de Janeiro Ed. UFRJ: 159-169.

2003 Aspectos da organização social de pescadores-coletores: região compreendida entre Ilha Grande e o delta do Paraíba do Sul, Rio de Janeiro. Pesquisas, Antropologia, 59: 9-163.

GLASSOW, M.

1999 Development of maritime adaptations during the Middle Holocene of the California Coast. Revista de Arqueologia Americana, 16: 155-182.

2002 Late Holocene prehistory of the Vandenberg region. In: Erlandson, J.M.; T.L. Jones (Eds.) Catalysts to Complexity: Late Holocene Societies of the California Coast, Cotsen Institute of Archaeology, University of California, Los Angeles: 183-204. 
HIRAGUCHI, T.

2003 Prehistoric and protohistoric whaling, and diversity in Japanese foods. Report and Proceedings: Summit of Japanese Traditional Whaling Communities 1: 23-47.

JERARDINO, A.; PARKINGTON, J.

1993 New evidence for whales on archaeological sites in the south-western cape. South African Journal Science, 89: 6-7.

KLEIN, R.G.; CRUZ-URIBE, K.

1984 The analysis of animal bones from archaeological sites. Chicago: University of Chicago Press.

LIMA, T.A.

2000 Em busca dos frutos do mar: os pescadores-coletores do litoral centro-sul do Brasil. Revista da USP, 44: 270-327.

LYMAN, R.L.

1989 Seal and Sea Lion hunting: A zooarchaeological Study from Southern Northwest Coast of North America. Journal of Archaeological Science, 8 (1): 68-99.

MARSHALL, F.; PILGRAM, T.

1993 NISP vs. MNI in quantification of bodypart representation. American Antiquity, $58(2): 261-269$.

MONKS, G.

2005 An oil utility index for whale bone. In: Monks, G. (Ed.) 9th ICAZ Conference, Durham 2002: The Exploitation and Cultural Importance of Sea Mammals. Oxford, Ed. Oxbow Books: 138-153.

MULVILLE, J.

2002 The role of Cetacea in prehistoric and historic Atlantic Scotland. International

NEVES, W.A. Journal of Osteoarchaeology, 12: 34 - 48.

1988 Paleogenética dos grupos pré-históricos do litoral sul do Brasil (Paraná e Santa Catarina). Pesquisas, Antropologia, 53:15. 175.

NEVES, W.A.; BLUM, M.

1998 Afinidades biológicas entre populações pré-históricas do centro-sul brasileiro: uma análise multivariada. Fronteiras, 2: 143-169.

OLIVEIRA, M.S.C. de

1996 Distribuição espacial de sambaquis em Joinville-SC: exercício geoestatístico preliminar sobre a variação morfométrica dos sítios. Revista Paranaense de Geografia, 1:17-27.

PAYNE, R.

2000 Entre ballenas. Buenos Aires: Emecé Editores.
PERRIN, W.F.; WÜRSIG, B.; THEWISSEN, J.G.M.

2002 Encyclopedia of marine mammals. San Diego: Academic Press.

PORCASI, J.F.; FUJITA, H.

2000 The dolphin hunters: a specialized prehistoric maritime adaptation in the Souther California Channel Island and Baja California. American Antiquity, 65 (3): 543-566.

PORCASI, P.; PORCASI, J.F.; O'NIELL, C.

1999 Early Holocene coastlines of the California Bight: The Channel Island as first visited by humans. Pacific Coast Archaeological Society Quarterly, 35 (2-3): 1-23.

PROUS, A.

1992 Arqueologia Brasileira. Brasília: Ed. UnB.

REITZ, E.J.; WING, E.S.

1999 Zooarchaeology. Cambridge: Cambridge University Press.

ROHR, J.A.

1967 O sítio arqueológico de Alfredo Wagner, SC VI 13. Pesquisas, Antropologia, 17: 2-24.

1977a O Sítio Arqueológico do Pântano do Sul SCF-10. Florianópolis: IOSC.

1977b Terminologia Queratosseodontomalacológica. Anais do Museu de Antropologia UFSC, 9-10 (1): 5-83.

SAVELLE, J.M.

1994 Prehistoric exploitation of white whales (Delphinapterus leucas) and (Monodon monoceros) in the eastern Canadian Arctic. Meddelelser om Gronland, Bioscience, 319: 101-117.

SAVELLE, J.M.

1995 An ethnoarchaeological investigation of Inuit beluga whale and narwal harvesting. In: McCartney, A.P. (Ed.) Hunting the largest animals: native whaling in the Western Artic and subartic, Canadian Circumpolar Institute, Studies in Whaling n'3: 127-148.

1997 The role of architectural utility in the formation of zooarchaeological whale bone assemblages. Journal of Archaeological Science, 24 (10): 869-885.

SAVELLE, J.M.; MCCARTNEY, A.P.

1999 Thule Eskimo bowhead whale interception strategies. World Archaeology, 30 (3): 437-451.

SAVELLE, J.M.; MCCARTNEY, A.P.; DYKE, A.S.

2001 Human predator and migratory megafauna: the case of Thule inuit bowhead whaling. In: Gerlach S.G.; Murray, M.S. (Eds.) People and wildlife in Northern North America, BAR International Series, 944: 242-254. 
SCHIAVINI, A.C.M.

1987 Una aproximación a la predación de los aborígenes prehistóricos del Canal Beagle sobre los pinnípedos. 2 a Reunião de Trabalhos de Especialistas em Mamíferos Aquáticos da América do Sul. Rio de Janeiro: 81-89.

SCHMITZ, P.I.; BITENCOURT, A.L.V.

1996 O sítio arqueológico de Laranjeiras I, SC. Escavações arqueológicas do Pe. João Alfredo Rohr, S.J. Pesquisas, Antropologia, 53: $13-76$.

SCHMITZ, P.I.; VERARDI, I.

1996 Cabeçudas: um sítio Itararé no litoral de Santa Catarina. Escavações arqueológicas do Pe. João Alfredo Rohr, S.J. Pesquisas, Antropologia, 53: 125-181.

SCHMITZ, P.I.; DE MASI, M.A.N.; VERARDI, I; LAVINA, R.; JACOBUS, A.L.

1992 O sítio arqueológico Armação do Sul. Escavações arqueológicas do Pe. João Alfredo Rohr, S.J. Pesquisas, Antropologia, 4I8: 11-220.

SCHMITZ, P.I.; VERARDI, I; DE MASI, M.A.N.; ROGGE, J.H.; JACOBUS, A.L.

1993 O sítio da Praia de Laranjeiras II. Uma aldeia da tradição ceramista Itararé. Escavações arqueológicas do Pe. João Alfredo Rohr, S.J. Pesquisas, Antropologia, 49: 7- 181.

SCHMITZ, P.I.; ROSA, A.O.; IZIDRO, J.M.; HAUBERT, F.; KREVER, M.L.B.; BITENCOURT, A.L.; ROGGE J.H.; BEBER, M.V.

1999 Içara: um jazigo mortuário no litoral de Santa Catarina. Pesquisas, Antropologia, 55: $1-164$

SEARS, R.

2002 Blue whale. In: Perrin, W.F.; Würsig, B.;
Thewissen, J.G.M. (Eds.) Encyclopedia of Marine Mammals. California, Academic Press: $112-116$

SILVA, S.B. DA; SCHMITZ, P.I.; ROGGE, J.H.; DE

MASI, M.A.N.; JACOBUS, A.L.

1990 O sítio arqueológico da Praia da Tapera: um assentamento Itararé e Tupiguarani. Pesquisas, Antropologia, 45: 9-210.

SIMÕES-LOPES, P.C.; PALAZZO, J.T.; BOTH, M.C.; XIMENEZ, A.

1992 Identificação, movimento e aspectos biológicos da baleia franca austral (Eubalaena australis) na costa do Brasil. In: Anais de la III Reunión de Trabajos de Espertos En Mamíferos Acuáticos de América Del Sur. Montevideo: 62 - 63.

SIMÕES-LOPES, P.C.; XIMENEZ, A.

1993 Annotated list of the cetaceans of Santa Catarina coastal waters, southern Brazil. Biotemas, 6 (1): 67-92.

SIMÕES-LOPES, P.C.; DREHMER, C.J.; OTT, P.H.

1995 Nota sobre os Otariidae e Phocidae (Mammalia: Carnivora) da costa do Rio Grande do Sul e Santa Catarina, Brasil. Biociências, 3 (1): 173-181.

SMITH, A.B.; KINAHAN, J.

1984 The invisible whale. World Archaeology, 16 (1): 89-97.

TENÓRIO, M.C.

1999 Os fabricantes de machado da Ilha Grande. In: Tenório, M.C. (Ed.) PréHistória da Terra Brasilis. Rio de Janeiro, Ed. UFRJ: 233 - 246

ZAR, J.H.

1999 Biostatistical analysis. 4th ed. New Jersey: Prentice-Hall. 